\title{
New Formation of Islamic Legislative System by Muhammad Iqbāl
}

\author{
Salahuddin Mohd. Shamsuddin
}

\author{
Faculty of Arabic language at Sultan Sharif Ali Islamic University \\ Brunei Darussalam
Corresponding author details: Prof. Dr. Salahuddin Mohd. Shamsuddin; shamsuddinsalahuddin@gmail.com

\begin{abstract}
If we want to study Muhammad Iqbāl's Islamic thought, we have to study his book: (Reconstruction of Religious Thoughts in Islam) before reading any book about him, as we cannot ignore this book on this subject, because the researcher cannot reach the depth of his thought and philosophy without studying this book. Iqbāl has philosophized in the statement of these complex topics that are related to "the science and spiritual experiences", the perception of the existence of God, the reality and habit, the human self, the compulsory and choice, the spirit of Islamic civilization, Ijtihād, and development of Islamic legislative system. Iqbāl's character in this book appears, as an Islamic poet, thinker and philosopher, in which we also see Iqbāl as he wants to develop a new Islamic science of speech. It should be noted that Muhammad Iqbāl addressed these topics with careful research and deep study in the light of the teachings of Islam and modern philosophy, and opened the doors of thinking about Islam to his contemporary thinkers and scholars and those who came after them. Iqbāl by his mentality and being influenced by the philosophical approach tends to the synthesis of this method of mental analysis, but because of his religious tendency, he also tends to correct the steps of thought itself by highlighting the Qur'anic view on the content of the mental experience to follow in its footsteps towards the truth, using the descriptive analytical approach that is always fit in the treatment of such topics.
\end{abstract}

Keywords: renewing Islamic thinking; proving God's existence by the reason; prophecy; Qur'anic view; Islamic legislative system; religious experience

\section{A SOPHISTICATED LEGISLATIVE SYSTEM IN THE OPINION OF IQBĀL \\ When Iqbāl wanted to rebuild the religious thought in Islam, it was natural that he addressed the subject of the legislative system in Islam to keep up with Muslims in the present life and to take the reins of life and civilization in the light of their faith and sharia. There is no doubt that the legislative system is the applied field of Islam, so he had to address some issues about Islamic law in some of his lectures.}

There is no doubt that the basic objectives of Islam are some high objectives of the reform on which the goodness of man is based in his life and hereafter, and they are as the following:

A. Freeing the human mind from the illusions, superstitions, traditions and misguidance with the doctrine of divinity (monotheism) and prophecy, calling on minds to think and consider and to demand the argument and proofs so that the legislation of sharia law reaches the truth and correctness.

B. Psychological reform of the individual and community through principled and fundamental provisions to regulate the behaviour of the individual, family and society, to safeguard the human rights and to ensure the integrity, happiness, progress and dignity of human beings.
It is clear from these two things that sharia is based on three foundations:

1) Islamic Faith

2) Spiritual worship such as the prayer and fasting

3) Law of the Judicial System for the regulation of transactions

The Qur'an contained the general provisions concerning these three foundations: The faith, worship, and transactions, and the Prophet's Sunnah detailed what was briefly stated by The Qur'an by saying and doing according to the requirements of things.

It is clear that the sources of Islamic law during the life of the Prophet Muhammad were the Qur'an, the Prophet's Sunnah and Ijtihad (50) or the mental conclusion in deriving the detailed provisions of sharia from the briefly stated matters. The sources of Islamic jurisprudence, then the sources of Islamic jurisprudence: The Qur'an, Sunnah, consensus and measurement became expanded.

Briefly we can say that the basis of Islamic legislation is based on the revelation and reason so that the mind completes and legislates according to a set of rules, so that the legislative system matches Muslim life at all times and places, depending on a mental rule, and this rule was decided by the scholars on the basis that the incidents and facts in the worship and the transactions are not limited to, and in each incident there is no text and it is unimaginable, 
and since the texts of sharia are infinitely limited in its nature, and the facts and arguments are infinite and unlimited, and the limited identification cannot control the unlimited requirements that the need has emerged for the reason necessarily, and measurement and diligence are a necessary need to continue to apply the legitimate provisions to people's lives and increasing developments.

Therefore, when the Ijtihad movement in Islamic jurisprudence stopped at the limits of the provisions and issues decided by the hard-working jurists, Islamic jurisprudence suffered a big setback, and moved away from the public life of the Islamic nation only as far as personal status was concerned, and became increasingly critical and far from reality by neglecting it; especially after Islamic societies opened up to Western civilization, and were directly affected in all areas of Islamic social and economic life, and the modern positive provisions and laws entered the entrance of provisions of sharia.

When the link between the life of Muslims and their law in the field of rights, provisions and organizations was severed, and the ensuing disruption of sharia law and glorification of legitimate principles arose a deep gap between Islam and the reality of social, political and economic civilization, thus putting forward several problems that are at the forefront of the discussions between Muslim intellectuals in the present reality, and these problems are:

1) Islamic law cannot be applied in contemporary life with regard to certain provisions that appear to be contrary to legitimate the human dignity and rights, such as cutting off the hand of the thief and stoning the fortified adulterer.

2) The inviolability of doctrinal provisions for development, because they are religious and not only legal, the religious rule is fixed and the legal provision accepts to be reviewed and modified in accordance with the requirements of the social life and the development of human thought; hence the lack of validity, meaning that the laws of Islamic jurisprudence are religious and not civil.

3) Islam's liberalization of the system of interest and profit in the commercial transactions and dealing with the banks while the contemporary economic life is based on dealing with the banks and loan and laws of interest and planning to promote the national economy based on the achievements of large projects thanks to these loans.

4) The existence of social and economic conditions that do not have a ruling in Islamic jurisprudence and cannot be ignored because Islam has not specified provisions for them, for example, Islam has specified the categories in which zakat is obliged within the limits of the old agricultural and economic conditions, but in the modern industrial and investment era there is nothing specific, as well as the insurance system at various levels not included in Islamic jurisprudence, does life in Islamic society decline at the limits of ancient life or move jurisprudence and keep pace with the development??

In response to these questions, Iqbāl found the objective reasons that led him to discuss Islamic law and make proposals for a sophisticated legislative system.

According to Iqbāl, Islam has created a cultural movement based on the view of the universe as an ever-changing movement, and ends up ruling that Islam - in order to build an undifferentiated human unity between dynasties and races - is based on the principle that spiritual life is the origin and origin of nation-building. (51) Iqbāl also believes that there is a link between the beginning of civilizational rising of Islam and the dying of ancient civilizations before the emergence of Islam, in order to confirm that the world needed a new culture, and that this new culture emerged from the Arabian Peninsula, and also confirms that the life when it needs the necessary guidance, the nature interferes in its orientation. (52)

Thus, Islam came as a heavenly message in order to achieve the principle of human unity and obedience to God alone, because the sincerity and obedience to God are a fidelity to our perfect nature. Islam also directed the thought towards the universe to infer its various changing manifestations of God's existence, ability and kindness. (53)

\section{RECONCILING BETWEEN THE FIXING AND CHANGING IN ISLAM}

Iqbāl explained that the Islamic society is based on reconciling the constant and the changing at first, there is a constant divine self, and there is a universe, which is a sign of divine self, and there are some fixed principles that control our lives and fix our feet in this changing universe, which necessarily requires a kind of change or development on the other hand; (54)

Iqbāl believed in the need to renew and develop the Islamic society in keeping with the natural law in ordinance to its biological and sociological phenomena, because the Qur'an itself - the Holy Book of Islam - confirms that the universe is constantly changing. Therefore, it cannot be an adversary of evolution, but we should not forget that the existence is not only a pure change; it also has some fixed elements; and for this view the modern mental doctrine should address the research of our existing systems. A nation cannot fully deny its past. (55)

Iqbāl tried to get to the heart of the problem of the development of Islamic legislation to the development of the Muslim community itself, so he discussed the basic sources of Islamic legislation and the rules established in the Qur'an regarding the dimension of the provisions, but he had to say that these assets are far from blocking the way to thinking about the development of legislation, linking this idea with the principle of ijtihad. (56) $\mathrm{He}$ bought an example from those examples that put by a Turkish poet Zia (57) as a problem of the development of Islamic legislation, which is the settlement between the women and men in the inheritance and divorce, he replied to the Turkish poet that the Qur'anic legislation related to this issue is a balanced legislation achieved by Islamic legislation in its society as a whole, in term of the principle that Islam is an integrated system that has achieved the balance and harmony between all the rights and duties of both men and women, and ended his speech in response to the Turkish poet by saying: If we study our law as for the expected revolution in the modern economic life, it is better to reveal in the origins of legislation some new aspects that have not yet been revealed to us, which we can apply with renewing faith in the wisdom of these principles. (58)

PRINCIPLE OF IJTIHAD IN ISLAM IN THE OPINION OF IQBĀL Iqbāl believed that Islam had recognised the principle of ijtihad and reconciling the constant and constantly changing, and it is known that the scholars of jurisprudence recognize ijtihad as one of the origins of legislation, but it is bounded to the conditions that are difficult to be found easily to them, thus it came to Islamic jurisprudence to close the door of ijtihad strictly, because of these conditions, and to take care of the risks that threatened the Islamic society as a result of that openness. 
The situation of Muslims has therefore been deadlockedand left behind. Iqbāl This is explained by Iqbāl as the tendency of jurists to preserve the fixed element and to obligate in the legislation and adherence to the doctrine for fear of the tyranny of the mentality that emerged among the speakers, and began to challenge many moral and religious values, then Sufism and Sufis came and there was a rebellion against the opinions of jurists, and the difference emerged between sharia (59), The truth (60), and Sufi method (61), which became strong by the movement of freedom from the law and indifference to the phenomenon and some fertile horizons opened up for the spiritual and philosophical experiences attracted a lot of minds and the foundations of the Islamic unity were almost ravaged by the storms, as the disaster: The fall of Baghdad came on the hands of Moghul, the jurists feared the fate of Islam and focused their efforts on imitating official doctrines in order to ensure the continuation of an orderly Islamic society. They were right and wronged in that case. Their right is due to the need for fixed elements in the life of society and that each system must resist against the forces of decay. The error is due to follow the fixed element to the point of dependency and traditionalism. The reaction occurred to Ibn Taymiyyah AlHanbali (62), who regained the right of Ijtihad. (63)

In modern times, the modern Movement of Turkey (64) in the opinion of Muhammad Iqbāl - was based on ijtihad, as two trends emerged at that time, one that considered priority to the state before the religion, and a trend that prioritized the religion. The first trend was that the State was the main factor that constituted all the other factors affecting the life of society, thus insisting on the distinction between the religion and the State, and Iqbāl was satisfied with the popularity of such a distinction but conservatively, simply saying that the state factor should be stronger than the factor of religion. Iqbāl also believes that the tendency of separation between the religious and the worldly powers is based on the distinction between the two elements: Physical and spiritual in the life.

Iqbāl sees that the State in the eyes of Islam, is the means by which ideal principles are transformed into spatial and temporal forces. Turkey's attempt to change the state system from an Islamic caliphate to a new republican system it is a proper attempt at jurisprudence, so that the only (Turkish) Islamic nation has been able to dust off the stalemate and is looking for a realistic world in which it is engaged in a conscious and open life, but there is a serious question faced by Turkey, and faced by the entire Muslim world: Is Islamic law evolvable? Iqbāl responds to this question in the affirmative tone, but it requires that the Muslim world has to face this question with a spirit of courage and independence of opinion, as 'Omar b. alKhațțāb was doing.

\section{PRINCIPLE OF UNANIMITY IN ISLAM IN THE OPINION OF IQBĀL}

Iqbāl believes that the principle of unanimity (65) is the most important legislative idea in Islam as it is one of the origins of legislation. Iqbāl says in this regard: It is strange that this general idea has intensified the controversy over it in the beginning of Islam, and has provoked a lot of scientific controversy, and has remained almost just an idea, and has rarely taken the form of a system in any country of Islam. Perhaps the unanimity turned into a fixed legislative system that was contrary to the political interests of the absolute rule that arose in Islam after the era of fourth caliph directly. I think that the successors of Banī 'Umayyah and Banī Al-'Abbās felt that their interest was achieved by referring the diligence to hard-working jurists more than by encouraging the formation of a group of the hardworking imams, which may become difficult to them.
However, it is entirely gratifying to find that the pressure of new global factors and the experiences of European peoples in politics have made the thinking of Muslims in the modern era influenced by the value and potential of the idea of unanimity, and that the spirit of democracy in Islamic countries and the gradual establishment of legislative assemblies are a great step towards the progress. When the opposing teams increased and became so many, the transfer of the right of ijtihad from the individuals representing the doctrines to an Islamic legislative body is the only form that the unanimity can take in modern times, and this transition ensures that the legislative debates can be benefited from the opinions of non-clerical people who have a strong vision of life. By this way only, we can bring strength and activity to the slumber of their legislative systems and follow them on the path of development. However, it will be difficult in India where it is doubtful that a non-Muslim legislature will be able to exercise the right of Ijtihad.

Two other questions about the unanimity are answered by Iqbāl in his book: Reconstruction of Religious Thoughts in Islam. The first question is: Is it right for the unanimity to change some provisions of the Qur'an? (66)

However, the most of fundamentalists declared that the unanimity cannot be a changer, then it cannot change any kind of the text or its provision.

Iqbāl responds to this question saying: There is no need to ask such a question in the presence of a Muslim audience, but I feel obliged to do so, because a writer from the West cited a very misguiding phrase in a book entitled "Islamic Material Theories" published by Columbia University, the author says, without supporting his statement by quoting any reference, that the Hanafi writers and Al-Mu'tazila consider that the unanimity may change the Qur'an, but we do not find in the books of Muslim about the legislation any justification for such a provision. Rather, the Prophet's own Hadith can have no effect on changing the Qur'an.

The second question is: Can the unanimity of Sahaba on some issues be compulsory for future generations after them?

Al-Shawkānī has elaborated on this issue and has provided the views of the jurists of different doctrines and he believed that there must be a difference here between the unanimity related to a fact and the unanimity concerned to a legal rule, i.e. a legal point, in the first case, as happened, for example, when the research arose that the two short Surat known as: (Al-Mu'awwazatain) were a part of the Qur'an or not? The unanimity of the Sahaba was that they were a part of the Qur'an, and we are obliged by their consensus because it is clear that only the Sahaba were so that they knew the truth of the matter.

As for the consensus on deciding a legitimate rule, it is only the subject of interpretation and I dare say, depending on AlKarkhi's view that the subsequent generations are not obliged by the consensus of the Sahaba. Al-Karkhì says: "The method of living of Sahaba is obliged by the things that are measured, and it is not what can be decided by the analogy,"

Another question may be asked about the legislative activity of a modern Muslim body, which, for the time being, must at least consist of men who are not familiar with the secrets of Islamic legislation, and that such a body may misinterpret sharia in an obscene error, so how can we avoid or at least limit the possibility of misinterpretation? He argues that in contemporary Muslim society, some scholars must be as the key members 
of the Islamic Legislative Assembly to be helpful in discussing the legislation. The only successful solution for the possibility of making interpretation mistakes is to reform the present legal education system in Islamic countries, expanding its reach and link it to the rational study of Islamic jurisprudence and modern legal jurisprudence.

At the end of his speech, Iqbāl said:

"This brief presentation may clearly show that neither the origins of our legislation nor the building of our doctrines, as we find them today, justify the present trend. The Islamic world, equipped with the deep thinking and new experiences, must courageously complete the renewal that awaits it. However, this renewal has a greater aspect than merely suiting the conditions and of modern life. The First wold War, with its legacy of Turkey's renaissance, recently described by a French writer as an element of stability in the Islamic world, and the new economic experience in close proximity to Islamic Asia must open our eyes to the meaning and destiny of Islam."

Humanity today needs three things: Interpreting the universe spiritually, freeing the spirit of the individual, and developing fundamental principles that have a global importance that guide the development of human society on a spiritual basis. There is no doubt that Europe has established its ideal systems on these foundations in modern age, but the experience has shown that the truth revealed by the mind cannot ignite the strong and sincere faith that the religion alone can ignite. This is the reason that the abstract thinking has only slightly affected people, while the religion has always been able to promote the individuals, changing the groups by throwing them and their shells and moving them from one situation to another.

Europe's idealism has never been one of the living factors influencing its existence, and therefore has produced a misguided self-looking for itself among some democracies do not know the kindness, all concerned with exploiting the poor for the benefit of the rich. Believe me, Europe today is the greatest obstacle to the moral advancement of man. The Muslim has these final opinions based on an inspiration that talk to people about the depths of life and existence. These opinions are apparently external, leaving their mark deep in the soul. The spiritual basis of a Muslim's life is a faith for which he can sacrifice his life Since the basic rule of Islam is that Muhammad is the last prophet and messengers, so Muslim should be one of the most spiritual peoples of the earth, and the first descendant of Muslims who have been rid of spiritual slavery in ignorant Asia were not so aware of the right meaning of this basic rule. Today, a Muslim must appreciate his position, rebuild his social life in the light of the final principles and draw from the objectives of Islam that have not yet been partially discovered - that spiritual democracy that is the end of Islam and its purpose. (68)

Finally, we can ask why Muhammad Iqbāl did not try to reshape Islam's moral theory derived from the Islamic perception of the universe and life, even though he was responsible for fulfilling this duty, within the scope of reconstruction of religious thinking in Islam.

In response to this question, Muhammad al-Katānī in his book "Muhammad Iqbāl, an Islamic thinker", depending on the book: "Moral Philosophy in Islamic Thought" authored by 'Ahmad Muhammad Șubhì, said: "There is no doubt that he did not feel that there was an urgent need for a Muslim to present a comprehensive Islamic moral theory, as long as the Muslim believes in the existence of God and believes the message of Prophet Muhammad, the result is that morality in Islam derives its standards and values from the orders of the Qur'an, its forbidden provisions and its directions, and from what is mentioned in the correct prophetic Sunnah to show us. As God Almighty says: "What the Prophet said, take it and what He has forbidden leave it." (69) It will remain the absolute criterion for the morality of a Muslim, even if we take the Sunni doctrine in the matter of good and evil. (70)

Nevertheless, Iqbāl did not ignore the need to discuss the major ethical issues, as he addressed in his third lecture (Reconstruction of religious thoughts in Islam) and discussed them in the light of some modern philosophical theories and the interpretations of the Qur'anic verses. In this context, Iqbāl tried to link the establishment of a positive philosophy that pushes the Muslim to work, explaining to him the meaning of individual responsibility, and the principle of freedom of will on rational grounds reinforced by Qur'anic verses. (71)

\section{CONCLUSION}

Iqbāl opposed to Western culture and the material theory of life, which arose from a false vision of the manifestations of the universe and its external nature, but did not contradict the renewal in the sense of developing, reviving or evaluating the construction of Islamic sciences by linking Islamic sciences to the modern sciences, and reconciling the heritage with the contemporary age, where he saw that "the human life over the time changes according to his perception of his tasks, and that the modern sciences and technological development changed many concepts were known to the people, and for this he called for the reconstruction of religious thought. He was one of those who called for linking between the originality of the heritage and contemporary age". This is further illustrated by this question: Why did Muhammad Iqbāl seek to rebuild or renew the religious thought? Muhammad AlKatānī replies: "He certainly sensed the intellectual emptiness that Muslim youth found in the light of the dominance of Western thought, because the Islamic resurgence has to be accompanied by a process of scrutinizing the results of Western thought, to turn its results into a positive factor in deepening religious thought, because the science of Islamic speech had stopped growing and developing, and did not remain at the level of current mental data. On the other hand, he sought to stop the current of the atheism among the young Muslims educated in Western culture, by offering a new understanding of the religious thought that reveals the true essence of Islam.

There is a historical antagonism between the preservation of fossilized authenticity and the movement towards the advancement. Iqbāl believes that the preservation of fossilized authenticity is as ugly in the matters of religion as it is in the other areas of human life. Religion has reached us from Adam through the ages, if religion was not scalable and elevated, it would not have been in the line with renewed life, Adam, the Father of Mankind would had been the last prophet and messenger, and a messenger would not have come, and a heavenly book would not have come down, but we have seen a long series of erasing and fixing, such as the sequence of days and nights, as Qur'an says: "God erases what he wants and preserves to Him the mother of the book", so the revelation a book after a book, and a sharia after a sharia proves that the evolution and advancement do not occur in human life only, but also in the religion. According to the developments in the social conditions the laws and provisions change. When the law of a nation loses its validity, it that sharia is removed, and another sharia is sent like the previous one or better than that, this change or that replacement or development or upgrading is a great sign to prove the existence of the God Almighty. 
The sequence of erasing and fixing was ongoing until the ccompletion of religion, which means that Islamic sharia is the last sharia, there is no chance for any change or replacement or erasing in it. Iqbāl addressed the genius of Islam accurately in his book (Reconstruction of Religious Thoughts in Islam) and said:

"There is no doubt that Islam is a final divine message, and an inclusive and comprehensive system that is suitable for everyone, and for every society, but no one ever thought it was an inclusive system of human life in which sense? Human life moves towards evolution and sophistication every moment. God said: "I have completed your religion for you, completed my grace and satisfied with Islam, as a religion for you", the meaning of the completion of religion in this verse is not that Islam is a rigid religion or has a fixed system, which is unfit for the development, because this meaning cannot go along with the changes of renewing life, because the life is moving towards the advancement, and the rigid system lags behind. Islam is a complete religion in the sense that it accepts the development and movement forward, it always fits with the progress as it has a quality of advancement, and complements all the requirements of renewed life. Islam is not that old building that was built entirely once, has not changed after that, and we cannot think of any change in its construction, and that building became now very old in the present era. On the contrary, Islam has the power to provide means to build beautiful new buildings fit for the requirements of any age, and to cover the needs of any society.

Islam considers that the freedom of individual and his unique personality is essential for the survival and progress of society, because a productive and fruitful society consists only of a balance between the uniqueness of individual and his association with the group, and the uniqueness of individual cannot remain but only if it is a part of a social system operating under the law of movement, such as the celestial bodies that are a part of the solar system, where we see each of them is moving and rotating in its own circle, but each has an independent presence. If there is a loss of balance in the movement or a malfunction in the rotation, the whole solar system will be corrupted, because the solar system consists of the combination of the power of attraction and movement of multiple planets, as well as the society is consisting of the individual and linking it to the group and the serious cooperation among all of its members. When a practical social system is generated, the unity is generated among its members from that system. Balance in the universe cannot remain without unity, he says:

All that's found in the universe is because of the unity. The life in this world is because of the unity. In Islam, there is a universal unity, based on the origins of monotheism, and Islam as a social system is a practical means of making the origins of unity (in the emotional and intellectual life of man) a reality cannot be ignored. The nation is made up of this unity and serious cooperation among its members. The aim of that unity among the members of society and the individuality of every individual and movement of each individual within the unity is the establishment of that particular system, which is still lurking in the conscience of the universe. The life and survival of the nation is also from the law of the movement, but this law appears in the life of the nation, in the movement of urbanization, and this movement of urbanization in the term Islam is called "Ijtihad", and Ijtihad is to uncover some new stages and find them and invent them in the fields of science and knowledge. If the thought and Ijtihad are rigid or degrading in a nation, the intellectual fall of its members becomes a graveyard for building its lofty destinies, and the morality and high destinies of the nation's survival and immortality must be improved, because the life of the nation is linked to the validity of the constant creation of thought. Iqbāl believes that Islam as a social movement proves the moving perception and rejects the rigid perception of the universe. The basis of life on eternal spiritual destinies, and the basis of its immortality is on the diversity and change, and the society based on this basic perception is in line with the law of change necessarily. In order to organize the social life, it must have some eternal origins and laws, because living in this changing universe can only be done with those origins and laws, and that fundamentalist movement that is in line with the law of eternal life is called in the term of Islam (Ijtihad). It should be noted that Iqbāl mentions this jurisprudence with different names such as: Changing and movement, which means the creativity, innovation, scarcity of thought and movement towards the work. Says:

A life in which there is no change at all, it is a death, because the life of the spirit of a nations is the struggle for the change.

We can say in the other words that the life has two sides, a fixed face, which is stable cannot be change, and a changing, moving, and coloured face, which is unstable. The first is the doctrine of monotheism, and the second is the image of Ijtihad, and Islam has reconciled these two aspects of life. On the one hand, Islam has given us valuable origins and principles, which are inclusive, comprehensive and timeless, by which we can establish our feet in this changing world, and on the other hand we have given the choice to develop those principles and rules to build a good and useful system through Ijtihad in the light of those eternal principles and rules. Iqbāl believes that the life of Islam is based on a combination of constant and changing, if this combination remains it can advance every moment. We do not want to discuss the subject of (Ijtihad), its historical backgrounds and the philosophy addressed by Iqbāl in his lectures with a deep research, but we want to mention that question raised by Iqbāl in his lectures: The Turks face this question today, but tomorrow the whole Muslim world will face it. The question is, Is Islamic law fit to accept the development and progress towards the advancement? The answer to this question is that Islamic laws and provisions accept the development, and are not rigid, but they are moving, as the second caliph 'Omar b. alKhattāan, said before Muhammad the Messenger of God: "God's book (Qur'an) is enough for us". Iqbāl believes that his saying shows his critical vision and moral audacity, because he wanted to say that the general provisions and principles with the legal formula mentioned in the Qur'an are related to the family, which is the basis of social life, and those provisions and principles cover all the needs of life that are renewed every moment and can be worked out easily according to the requirements of life at all times and places.

Can those origins and principles contained in the Qur'an be formed on the basis of the personal Ijtihad of a member of the nation?

The content of Iqbāl's words seems to be that the jurisprudence of an individual is limited to himself only, as for all members of the nation, God's saying will be used: "And their issue will be solved by "Shurā" amongst them.", so that the means of the new composition of the provisions can be provided after the deliberation of sessions and discussions among the members of the committee consisting of scholars and intellectuals and those who know the narrations and biography of Prophet's companions and, and, and, and etc. 
Finally, we must say that Iqbal focused in his book: (Reconstruction of Religious Thoughts in Islam) on his idea "the principle of movement". All beings are in constant motion, so we hear the sounds of "becoming in the universe" continuously. The life also moves and regenerates (whether individually or socially) as it is the river running with its moving waves. The creator of the universe has a renewed affair, and then this movement is not circular, but it is straight to Iqbāl, it means that history does not repeat its events, means that who was with us yesterday he is not with us today, and who is found with us today, will not be with us tomorrow. Thus, all assets, provisions and principles are evolving towards upgrading Those who say that Iqbāl was dreaming of the past, tending to the reactionary, and reviving the old, they oppresses him, because he did not dream of the past, he always looked to the future, he did not want to revive the old, but he wanted to rise up and move every moment, he did not want to repeat the lessons of the past, but he wanted to emphasize its importance to reform the present. We must not forget that the present is always born from the belly of the past, he called for the use of those useful lessons, as we see that if the tree trunks are found strong, bear fruit again after cutting their dry old branches, this process can be called (revival) but we call it (second genesis) or The new configuration).

\section{REFERENCES}

[1] There is a difference among the scholars about Ijtihād in the life of Muhammad the Prophet that is it was a source of legislation or not? See: 'Abdul Jalīl 'Abu Nașr. (1950). Jurisprudence of the Prophet. Cairo: 'Isā Al-Bābī Al-Ḥalabī Press.

[2] Reconstruction of Religious Thoughts in Islam. P. 168

[3] Ibid. P. 169

[4] Ibid. P. 170

[5] Ibid. P. 170

[6] Ibid. P. 191

[7] Meaning of Ijtihad is that the jurist of Islamic law should do his utmost to devise sharia law from detailed evidence for the conclusion of judgments, either to be established or to apply them. Imam Mālik and the most of the scientists of sharia see that its provision is compulsory for the people. (Muhammad Iqbāl as an Islamic thinker. Muḥammad al-Katānī p. 97) as he mentioned the meaning of Ijtihad quoted from the book (Revision of the Chapters by Imam AlQurāfī P. 190).

[8] Zia Choir Alp (1875-1924) is a Turkish poet and senior national leader who called for Turkish nationalism.

[9] Reconstruction of Religious Thoughts in Islam. p. 196.

[10] The sharia is the apparent face of Islam, i.e. its provisions and rules in the worship, transactions and beliefs, which is clear from the concepts of Islamic texts in the Qur'an and Hadīth.

[11] The truth is a way of Sufi method or is the cognitive knowledge that obtained by the Sufi after revealing the veil and watching the truth.
[12] The method is to describe the approach or behavior chosen by the Sufi himself from a spiritual exercise sport and psychological struggle related to the matters of the subconscious so that the soul or the heart can be cleaned and prepare to reveal the truth, and exceed the customs and formalities.

[13] He is the son of 'Abbās 'Aḥmad bin 'Abdul Halīm, alias Taqiyuddin Ibn Taymiyyah (661-728), a Sheikh of Islam, born and educated in Damascus during the Tatar march on the Islamic East, who promoted the message of reform and Islamic revival, and is one of the greatest men of the science of speech and builders of philosophical doctrine throughout the ages.

[14] Muhammad Iqbāl as an Islamic thinker. P: 98.

[15] This movement, carried out by Mustafa Kamal Ataturk in Turkey, who was a military commander in Turkey, rose to the highest positions in the Turkish army, and then became an army inspector in 1918, formed a revolutionary group of officers and tried to revolt against the caliphate and after succeeding in his attempt he formed a national government in Ankara. He declared that Istanbul's government was illegal and then the states recognized Mustafa Kamal for his government the republican regime after he abolished the caliphate and drafted a new constitution for the country in which he made the legislative sultanate in the hands of parliament. Mustafa Kamal was elected president of Turkish public and remained in the power until he died in 1938. He dissolved the religious methods, applied civil law instead of Islamic legislation and replaced Arabic letters with Latin in 1929. Salahuddin Mohd. Shamsuddin. Islamic trend in the Poetry of Muhammad Iqbāl. Pp. 317-318.

[16] Fact of the consensus is that the agreement of the people of Islamic science al-Fiqh of the Islamic nation on the one of the Islamic issues. The agreement is a participation in the words, the acts or the accreditation. The issue means here the legal, mental and customary issues. The Imam of the Two Holy Mosques said in the book: Al-Burhān (the evidence): "There is no sign of the consensus in mental sciences because the definitive evidence can be considered there, but the consensus is considered in the narrations only. Revision of the chapters. Al-Qurāfî. P. 144

[17] Cancelation in the term is removing the provision (the sentence) by a legitimate evidence, which is intended by the sharia as stated in the Qur'an while addressing the believers. Al-Zurqānī. 'Abdul 'Azīm. Manāhil Al-Irfān. Part 2, p. 110-111

[18] Imam Muhammad Ibn 'Alī Al-Shawkānī (1173-50 $\mathrm{AD}$ ) is a well-known hardworking jurist, has some books, including the book: Nail Al-Awțār in the secrets of the refreshment of the narrations, in which he discussed the issue of consensus.

[19] Reconstruction of Religious Thoughts in Islam. p. 206-208.

[20] Surah al-Hashr. Verse: 7

[21] Muhammad Iqbāl as an Islamic thinker. p. 78-79.

[22] Ibid. p. 78-79 